\title{
Entrepreneurial Orientations and Business Financial Performance: The Case of Micro Businesses in Tanzania
}

\author{
Riziki M. Nyello, Nuru Kalufya \\ Institute of Social Work, Dar es Salaam, Tanzania \\ Email: rizikim6@gmail.com,nkalufya@gmail.com
}

How to cite this paper: Nyello, R. M., \& Kalufya, N. (2021). Entrepreneurial Orientations and Business Financial Performance: The Case of Micro Businesses in Tanzania. Open Journal of Business and Management, 9, 1263-1290.

https://doi.org/10.4236/ojbm.2021.93068

Received: February 8, 2021

Accepted: May 25, 2021

Published: May 28, 2021

Copyright $\odot 2021$ by author(s) and Scientific Research Publishing Inc. This work is licensed under the Creative Commons Attribution International License (CC BY 4.0).

http://creativecommons.org/licenses/by/4.0/

(c) (i) Open Access

\begin{abstract}
Micro business in Africa including Tanzania does not perform well financially due to various business environmental challenges. In this line, entrepreneurial orientations are said to improve micro business financial performance regardless of unfavourable business environment. Despite such importance of entrepreneurial orientations, there was scanty knowledge on the influence of proactive and risk taking behaviour on business sales and costs. Focusing from the Contingency perspective, this article aimed at filling in such knowledge gap. Most studies examined the influence of entrepreneurial orientations on firm performance from the resource-based perspective. However, the influence of entrepreneurial orientations on firm performance depends on the match between entrepreneurial orientations and firm performance goals. The article involved 388 micro businesses from Dar-es-salaam, Mbeya, Morogoro, and Manyara. The questionnaire was used to collect data while Mean and Structural Equation Modeling (SEM) were used as data analysis techniques. The results revealed that proactive behavior had significantly positive influence on business sales and significantly negative influence on business costs. Furthermore, the risk-taking behaviour was found to have significantly positive influence on business costs. Among others, the article recommends that the micro business owners/operators should strengthen their entrepreneurial capacity together with their employees. It will be achieved by establishing sectoral associations in accordance with their business categories, i.e., trade, services and manufacturing in order to organize and access professional entrepreneurial trainings.
\end{abstract}

\section{Keywords}

Entrepreneurial Orientations, Business Financial Performance and Micro Businesses 


\section{Introduction}

The business structure in Africa is dominated by micro businesses that are expected to be an engine of economic development (Liedholm, 2002; Benzing \& Chu, 2012; Diyamett, 2012). Scarborough and Zimmerer (2008) argue that micro business sector is one of the key sectors in terms of job creation, economic growth, poverty alleviation and industrial development in the developing countries. Despite such importance, micro enterprises face several business challenges including low sales revenue and high cost of doing business (Marwa, 2014) that significantly hampers their financial performance. Financial performance may reflect the overall financial health of a business and it is differently measured. It is argued that return on investment (ROI) is the powerful and popular financial performance measurement (Botchkarev \& Andru, 2011). However, ROI is the function of revenues and costs (ibid). In this vein, this article defines financial performance as the ability of a firm to increase its sales revenue while reducing business costs.

Micro businesses' economic benefits can be largely grouped into two major categories, i.e., employment provision and poverty reduction. For instance, Diyamett (2012) argues that the micro businesses which employ between 1 to 4 people as per URT (2003), are one of the leading employers, next to agriculture, in Tanzania. However, the performance of micro businesses in Tanzania is not promising (Mashimba \& Kühl, 2014). According to Olomi (2009), the business sector is dominated by informal micro businesses with low incidence of graduation to formal small and medium businesses. Micro enterprises, i.e., trade, service and manufacturing, remain marginal players creating and sustaining low quality jobs and unable to contribute in the economy (Olomi, 2009). This means that micro businesses in Tanzania have insignificant contribution in the gross domestic product (GDP) of the country. Its characteristic of being informal also raises a doubt on its contribution to the government revenues through tax payments.

Different authors mentioned several factors that influence micro business performance. These factors include the availability of capital, support from family and friends, hard work (Neshamba, 2000; Pratt, 2001) and, linkage between micro businesses and large firms (Soderbom et al., 2006). Other factors include regulations, corruption and capital constraints (Macculloch, 2001; Pope, 2001; Kiggunda, 2002; Agboli \& Ukaegbu, 2006; Inegbenebor, 2006), lack of access to financial capital (Umoh, 2006; Mbogo, 2010) and, business training (Kessy \& Temu, 2010).

Furthermore, other studies such as Mnenwa and Maliti, (2009) and MoIT (2012) also mention factors that influence micro business performance. Mfaume and Leonard (2004) argue that legal requirements in force, security and safety reliability in the business area, customer's attitude towards the merchandise and environment, pricing and capitalization structure and management competence of the business owner are the factors which influence business performance. 
Mnenwa and Maliti (2009) identified several factors that influence business performance such as tax incentives, loans, grants, market information, regulatory framework, financial services, marketing services and, technical and management training services.

Even though several challenges facing micro businesses in Tanzania have been mentioned, there are other micro businesses that perform well (Olomi, 2009). This may be contributed by being entrepreneurially oriented. It is also agreed that entrepreneurial orientation has relatively greater influence on business performance (Lumpkin \& Dess, 2001; Wiklund \& Shepherd, 2004). Businesses that have entrepreneurial orientation perform better than others (Semrau et al., 2016). More importantly, entrepreneurial orientation may enable micro businesses to address the environmental challenges that influence business financial performance. This is supported by the prior studies such as of Lumpkin \& Dess, (2001); Wales et al., (2013); Redipere, (2014) which argue that regardless of unfavourable business conditions, an entrepreneurially oriented-business perform well. This may not be surprising in Tanzania that despite the mentioned business challenges, there are few businesses that perform well which might also be contributed by entrepreneurial orientation.

Entrepreneurial orientation is defined as a process of making strategies and developing styles of firms that involve themselves in entrepreneurial activities (Lumpkin \& Dess, 2001). Entrepreneurial orientation includes three traits, i.e. innovation, proactive behaviour and risk taking (Avlonitis \& Salavou, 2007). Lumpkin and Dess (1996) define the mentioned components of entrepreneurial orientation. They define proactive behaviour as the process of seeking opportunities and being forward-looking in developing new products or services before being discovered by the competitors, while forecasting the future demand. Venkatraman (1989) defines proactiveness as the process of seeking new opportunities which may or may not related to the present line of operations, introduction of new products and brands ahead of cometitors, strategically eliminating operations which are in mature or declining stages of the life cycle (Cited by Rezaei \& Ortt, 2018). Risk taking has been defined by Lumpkin and Dess (ibid) as the willingness to take bold action such as investing in unknown markets and investing in the business with uncertain outcomes.

According to Lumpkin and Dess (2005), innovation is categorised into three groups. These groups are product-market innovation, technological innovation and administrative innovation. Product-market innovativeness refers to ability to understand the market, product design and innovation in marketing. Technological innovativeness refers to research and engineering efforts towards developing a new product or process. Administrative innovativeness refers to innovations in management systems and structures. It is however argued that innovation is an outcome of proactive behaviour because entrepreneurs can promote a proactive behaviour to enhance innovativeness and proposing innovative solutions (Ahlin et al., 2012). Furthermore, innovation depends on the collection 
and assessment of market information which is an outcome of the proactive behaviour (ibid). With this fact, the article mainly focuses on proactive behaviour and risk taking as the major entrepreneurial orientation.

Prior studies of Mahmood and Hanafi, (2013); Syed et al., (2017) consider entrepreneurial orientation as the resource and assessed its influence on business performance basing on the Resource-Based View (RBV). The influence of entrepreneurial orientation on business performance, however, may be determined with the fit between entrepreneurial orientation and the environment in which the business is operating (Lumpkin \& Dess, 2001). Prior studies such as Lumpkin and Dess (2001); Kraus et al., (2012); Ndubisi and Iftikhar, (2012) examined the influence of entrepreneurial orientation on business financial performance basing on the contingency perspective. However, these studies were conducted in the developed countries where the context can be different from that of developing countries hence there is limited knowledge on the influence of entrepreneurial orientations on business financial performance from the contingency perspective. In addition, entrepreneurial orientations may not have the same influence on firm's revenues and costs despite the fact that together they form the financial performance construct (Nyello, 2018).

It is therefore important to investigate the influence of entrepreneurial orientations on micro business financial performance. However, this article contends that there must be a fit between entrepreneurial orientations and business financial performance. The article therefore informs the body of knowledge on the relationship between entrepreneurial orientation and business financial performance by applying contingency perspective that has been limitedly applied by the reviewed empirical studies from the developing countries like Tanzania. It is also an agenda on how micro businesses can perform well financially in order to boost the Tanzania economy. This is due to the fact that micro businesses form the larger part of business structure in Tanzania (Olomi, 2009). In this vein, it is of great interest to policy makers to examine issues that promote the financial performance of micro businesses and entrepreneurial orientation may be one of them.

\section{Literature Review}

\subsection{Theoretical Literature Review}

Under Contingency perspective, the focus of entrepreneurship orientation performance relationship is mainly on the financial performance (Rauch et al., 2004). The Contingency theory was used to examine the influence of entrepreneurial orientation on micro business financial performance. There is significant attention by entrepreneurship researchers in examining the entrepreneurship behaviours-performance relationship basing on the contingency approach (Lumpkin \& Dess, 2001). For instance, Gray and Wert-Gray (2012) reiterate that an entrepreneur is the one who links the business elements of the 
firms' internal and external environmental factors. It was furthermore argued that entrepreneurial orientation is a strategy making process that provides the guidelines for a business to make entrepreneurial decisions and actions (Wiklund \& Shepherd, 2003).

The application of the Contingency theory in studying organizations started in 1950s as an answer to the scientific management and human relations' arguments that organizations' diversity does not dispute the fact that there is 'one best way' to organize (Weill \& Olson, 1987). The theory states the context that determines the best strategy for a firm to organize itself in order to enhance its performance. Various contingency theorists such as Burns and Stalker (1961); Lawrence and Lorsch (1967) examined different factors that determine firm performance. Several contingent variables such as technology, organisation structure, environment, and business size were examined. However, the contingency approach was criticized for leaving people behind in the analysis (Weill \& Oslon, 1987).

In 1983, the Contingency Approach was started to be used in the management information system and included people as the contingent variable. In this case, researchers such as Kaiser and Bostrom (1982) and Wiess, (1983) began to look at the fit between individual personality and information system. Despite the possible relationship between individual personality, information system and business performance, early contingency theorists just considered the 'fit' between individual characteristics and information system. However, in 2000, researchers (such as Li et al., 2008; Kraus et al., 2012) linked the Contingency theory with business performance.

Considering the aforementioned development of Contingency theory, the theory has been widely accepted in explaining the influence of entrepreneurial orientation on firm performance particularly in the hostile environment ( $\mathrm{Li}$ et al., 2008; Kraus et al., 2012; Ndubisi \& Iftikhar, 2012). For instance, Kraus et al., (2012) affirm that entrepreneurial orientation contributes to small firms' performance during a recession environment. Also Escribá-Esteve et al. (2008) agree that entrepreneurial orientation enables a firm to increase its sales revenue even during the period of market turbulence. It is possible that a firm takes proactive actions in looking for opportunities to enhance its performance (ibid). Furthermore, Semrau et al. (2016) revealed that entrepreneurial orientation enhances firm's capacity to overcome difficulties caused by unfavourable conditions in the context in which a firm operates.

The aforementioned studies show that Contingency theory is also used to examine an influence of entrepreneurial orientation on business performance. The prior empirical studies also show that entrepreneurial orientation can be used to overcome business challenges and hence improving business performance considering the contingency view. However, the mentioned studies were conducted in the developed economies in which most businesses are formally established (Semrau, Ambos, \& Kraus, 2016). This indicates that there is limited 
knowledge on the application of Contingency theory in examining entrepreneurial orientation-business performance relationship in both formal and informal businesses that are found in the developing economies such as Tanzania.

Most micro businesses established in Tanzania are informal (MoIT, 2012) and characterized by several business challenges such as poor market, high costs of inputs, low prices of products sold, low demand for the product, compliance to legal requirements and financing (Mfaume \& Leonard, 2004; Mnenwa \& Maliti, 2009; MOIT, 2012). Entrepreneurial orientation may address the mentioned business challenges and improve micro business financial performance. Moreover, this article argues that being entrepreneurially oriented is not sufficient to improve micro business financial performance. The business financial performance may be determined with the strategic fit between the acquired entrepreneurial orientations and the financial performance goals. With this fact, it is important to examine the influence of entrepreneurial orientation on micro business financial performance considering the contingency view.

\subsection{Empirical Literature Review}

\section{Entrepreneurial Orientations and Firm's Financial Performance}

Entrepreneurial orientations were found to have significant influence on firm' performance (Lumpkin \& Dess, 2001; Mahmood \& Hanafi, 2013; Radipere, 2014; Syed et al., 2017).

Syed et al. (2017) conducted a study on entrepreneurial orientation and business performance of manufacturing sector small and medium scale enterprises in Punjab Pakistan and revealed a significant relationship between entrepreneurial orientations and firm's performance. However, the aforesaid study involves the manufacturing sector only and excluded other business categories i.e. trade and services. Lumpkin and Dess (2001) conducted a study which linked two dimensions which are entrepreneurial orientation to firm performance the focus being the mediating role of environment and industry life cycle. The study investigated how entrepreneurial orientations are related. Also, the study aimed to explain how their functions differ in the environments in which firms exhibit the orientations to strategy making. The findings revealed that firms in hostile environment or in industries, where competition of customers and resources is intense, are more likely to benefit through entrepreneurial orientations. However, the study by Lumpkin and Dess (2001) was conducted in the United States of America where the contextual characteristics might not be similar to Tanzania.

In addition, Mahmood and Hanafi (2013) conducted a study on entrepreneurial orientation and business performance in Malaysia. It focused on competitive advantage as a mediator. The study by Mahmood and Hanafi (2013) revealed that there is significant relationship between entrepreneurial orientation and business performance. However, the study by Mahmood and Hanafi (2013) considered business performance as a single dimensional factor and not multi-dimensional factor. Entrepreneurial orientations may have different influence 
on the individual performance indicators.

The same argument that entrepreneurial orientations significantly influence business performance was supported by several other studies (Such as Kraus et al., 2012; Rosenbusch et al., 2013; Lechner \& Gudmundsson, 2014; Kollman \& Stockman, 2014; Radipere, 2014). With this fact it is likely that entrepreneurial orientation has an influence on the reduction of business sales and costs. For instance, it is possible that the possession of suppliers' information as a result of proactive behaviour may reduce the business operating costs. Hence, it is likely that entrepreneurial orientation to have an influence on micro business costs. Entrepreneurial orientation may also potentially influence business sales. The business led by the business owner/operator with entrepreneurial mindset is expected to perform higher financially through the exploitation of market opportunities. However, prior studies (like Hughes \& Morgan, 2007; Kraus et al., 2012; Lechner \& Gudmundsson, 2014) argue that entrepreneurial orientation dimensions have different effect on firm performance. On the contrary, other prior studies (like Wang \& Yen, 2012; Kollman \& Stockman, 2014) argue that all entrepreneurial orientations have the same influence on firm performance.

\section{Proactive Behaviour and Firm Financial Performance}

Proactive behavior may have an influence on the firm's financial performance. Syed et al. (2017) attest that proactive behaviour influences business performance by maintaining business position in the market. Likewise, Rezaei and Ortt (2018) argue that proactiveness has the positive influence on sales and market performance of a firm. In this case, proactive behavior in a firm may enable a firm to financially perform well because of its ability to influence the market behavior and make a firm a market leader. Supporting the previous empirical studies, Brege and Kindstrom (2020) described the proactive market strategies that make a firm being successful. These strategies include market shaping, customer engagement and innovation leadership. But the aforesaid study was a qualitative study and conducted in the developed economy. Lumpkin and Dess (2001) also argue that proactive behavior has the positive influence on the firm's financial performance. However, authors measured financial performance in terms of sales growth only while financial performance is a multidimensional variable measured by more than one dimensional item. This implies that whose findings cannot be generalized to the firms operating in the developing economies because they have different characteristics i.e. majority being quite informal. Despite the limitations of some of the prior empirical literature, the article hypothesized that:

\section{$H_{1 a}$ : Proactive behaviour positively influences micro business sales.}

$H_{1 b}$ : Proactive behaviour negatively influences micro business costs.

\section{Risk-Taking Behaviour and Firm Performance}

There have been different arguments on the influence of risk taking behavior and firm performance. For instance, Kraus et al. (2012) claim that risk orientation has an influence on business growth. Davis, Bell, Pyne and Kreiser, (2010) 
revealed that top managers with high tolerance risk behavior positively impact firm's performance. Likewise, Lumpkin and Dess (2001) argue that risk taking has an influence on business financial performance because they influence business sales growth. However, the study treats financial performance as a single dimensional variable while it a multidimensional variable explained by more than one item. Prior empirical studies (i.e. Carton \& Hofer, 2006; Madrid-Guijarro et al., 2007; Ahmad \& Ghan, 2010) argue that business performance is the multidimensional factor. On the contrary, other studies (like Hughes \& Morgan, 2007; Lechner \& Gudmundsson, 2014; Kollman \& Stockman, 2014) agree that risk taking behavior has negative effect on firm performance.

More specifically, Rezaei and Ortt (2018) argue that risk-taking behavior has negative influence on the production performance of firm. Olaniran, Namusonge and Muturi (2016) argue that risk-taking behaviour have negative relationship with both returns on assets (ROA) and returns on equity (ROE). Despite the fact that the aforesaid study explains the influence of risk-taking behaviour on the financial performance of firm, it only focused on the firms that were listed in the Nigeria Stock Exchange. However, Kosa, Mohammad and Ajibie (2018) came up with the qualitative information to explain why risk-taking behavior has negative influence on firm performance.

Kosa et al. (2018) found that the calculated risks had negative influence on firm performance. They further revealed that most managers are not willing to allow their employees to take the calculated risk i.e. to try new ideas or products. Instead, only managers are struggling to search for new opportunities which promote risk-aversion behaviour among the employees. But they admit that extreme risk taking can negatively affect the organization because it bears the undesirable risks including, but not limited to, loss of money, equipment, key personnel and hence poor performance. In this fact, Kosa et al. (2018) advocate for the organizations to take the calculated risk meanwhile allow their employees to take it. Based on the aforementioned discussion, the article hypothesized that:

$H_{2 a}$ : Risk taking behaviour positively influences micro business sales.

$H_{2 b}$ : Risk taking behaviour positively influences micro business costs.

\section{Research Methods}

The article adopted the cross sectional design because data were collected only once and businesses were divided into three sub-groups i.e. those dealing with trade, services and manufacturing. According to the Tanzania Ministry of Industry and Trade (2012), businesses are divided into three groups i.e. the ones dealing with trade, services and manufacturing. Wang \& Cheng (2020) argues that the cross-sectional research design enables the researcher to have a greater control over precision of estimates in sub-groups. Moreover, the article adopted the deductive approach. According to Holloway (1997), the deductive approach begins with the predetermined hypothetical relationship between research variables or theoretical framework and use the collected data from the field to con- 
firm or verify it. This article intended to examine an influence of entrepreneurial orientations on financial performance. It firstly examined the cause-effect relationship between entrepreneurial orientation and micro business financial performance. It also developed the theoretical framework that was supposed to be confirmed. For this reason, the article used deductive approach whereby the theoretical framework was initially developed and data were used to confirm it.

The article was conducted in Dar es Salaam City, Mbeya City, Morogoro region and Manyara region. Mbeya and Dar es Salaam were chosen because they have relatively higher business densities while Manyara has relatively lower business density (MoIT, 2012). Also, Dar es Salaam was chosen since it was also considered as the commercial city and business hub (NBS and Regional Commissioner's Office, 2014). According to the household budget survey (HBS) of 2012, the main income generating activity for Dar es Salaam residents was the sales of goods, purchases from suppliers for resale (trade) and sales of manufactured products (manufacturing) which made a total of $88.4 \%$ (NBS and Regional Commissioner's Office, 2014). Morogoro region was chosen because its business structure has been experiencing an increase in informal or petty trade sector which is formed by street vendors and artisans who are still at the micro level (Adahl, 2007). In this vein, Morogoro region was chosen because of an increase in micro businesses in its business structure and moderate business density (Adahl, 2007; MoIT, 2012).

In between 2006 and 2009, Manyara region was regarded as one among the poorest regions in the country with the regional per capita income of TZS 313,894 per person (SIDO, 2009). However, in 2012, Manyara region was the $8^{\text {th }}$ region in terms of high regional per capita GDP, amounted to TZS 1,494,161 (NBS, 2013) and the region is no longer regarded as one of the poorest regions in Tanzania. Despite its impressive economic performance, Manyara region is said to be one of the regions that have the relatively lower micro business density in Tanzania (MoIT, 2012). Hence, the selection of the mentioned research areas eliminated sample biasness because the whole business population basing on their densities was well represented.

Population of the article consisted of micro businesses operating in Tanzania Mainland. The micro businesses are the largest employers of Tanzanians compared to other businesses and they are estimated to be 3,059,906 (MoIT, 2012). Out of them, those dealing with trade are 1,710,884, services are 942,596, and manufacturing are 406,426 (MoIT, 2012). Most of these businesses are sole proprietorships and quite informal, i.e. not registered and licensed, even though they contribute in the economy in terms of employment creation. The units of enquiry were micro business owners and operators who were expected to have adequate information on the business financial performance and adequately involved in the day-to-day management of a business. This is supported by Yang (2008) who argues that business owners /top managers (operators) are the most informed individuals about their firm's overall operational activities. 
The stratified sampling technique was used to sample the respondents used in this article. This technique was used because micro businesses were categorized into three groups, namely the ones that were dealing with trade, services and manufacturing. It was important to identify the mentioned categories because the article intended also to gather information on the influence of entrepreneurial orientations on micro business financial performance across micro business categories. In addition, the use of an adequate and unbiased sample size is one of the important decisions because it determines the extent to which the research findings present the entire population. Different authors argue for the need of having an adequate sample size in quantitative studies. For example, Hair et al. (2010) argue that a sample size of at least 100 is required for the use of parametric tests. In order to get reliable results, Roscoe (1975) recommended a sample size that ranges between 30 and 500 respondents. A sample size of 200 is adequate for the use of parametric tests and ensuring the reliable results (Yuksel et al., 2010).

Moreover, Krejcie and Morgan (1970) developed a standardized table which indicates that the sample size should be 384 when the population size is at least 100,000 at the significance error of 0.05 . The sample size of this article was 400 micro businesses and the population size was 3,059,906 micro businesses and 388 respondents were contacted and involved in this article. This article applied Taro Yomane's formula (i.e. $S=n /\left(1+n(e)^{2}\right)$ as cited by Ahuja, (2001) to determine the sample size. The sample size was calculated at 5\% margin error and $95 \%$ confidence interval in order to arrive at the maximum sample size. More clarifications are shown in the following mathematical calculation:

$$
\begin{aligned}
S & =N / 1+N(e)^{2} \\
& =3,059,906 / 1+3,059,906(0.05)^{2} \\
& =3,059,906 / 1+7650.765 \\
& =399.9 \approx 400
\end{aligned}
$$

Table 1 shows the population size, sample size and the distribution of sample size basing on micro business categories, namely trade, services and manufacturing. It also shows the number of micro business were multiplied by proportions in order to determine the sample size in each category. With reference to the same table presented thereafter, the sample size of micro business dealing with trade was 224; services, 123; and manufacturing, 53 which made a total

Table 1. Sample size at 5\% sample error.

\begin{tabular}{ccccc}
\hline S/N & Business Category & Number of Micro businesses & Proportion $^{*}$ & Sample Size* $^{*}$ \\
\hline 1 & Trade & $1,710,884$ & 0.559 & 224 \\
2 & Service & 942,596 & 0.308 & 123 \\
3 & Manufacturing & 406,426 & 0.133 & 53 \\
& Total & $3,059,906$ & 1.000 & 400 \\
\hline
\end{tabular}

Source: MoIT (2012), and *Researcher's Calculations. 
sample size of 400 :

This article used the questionnaire to collect data from the respondents. The researchers administered the questionnaire in order to collect the quantitative data. The questionnaire was designed in the Likert Scale of 5 points $(1=$ strongly disagree to 5 strongly agree). Many scales have been developed and are used to measure the perceptions of people towards a given research variable (Hinkin, 1995). However, the Likert scale of five points was adopted because an increase in the scales from five to seven or nine points does not improve the reliability of ratings (Elmore \& Beggs, 1975). Also, the article focused on the composite scores and not the single item. This is because the composite scores are more reliable than the single item (Bisbe et al., 2006).

In data analysis, this article applied Mean, percentages and Structural Equation Modeling (SEM) analysis to analyse the collected data. Mean scores were applied in order to rank the key variables with their specific items while percentages were used to analyse respondents' and micro business' profile. The path analysis as the structural equation modeling technique was used in this article to test the hypotheses. The path analysis is the structural equation modeling that examines the "web" of relationship among the research variables (Jackson et al., 2005) which is also known as structural relationship (Hair et al., 2010) using path diagram.

In using SEM, the researchers assessed the goodness of fit indices, namely absolute fit indices, incremental fit indices and parsimony fit indices. The absolute fit indices include Goodness of Fit Index (GFI) and Root Mean Square Error Approximation (RMSEA) which were used to examine the extent to which the prior model fits well the data (McDonald \& Ho, 2002). The recommended GFI is 0.90 (Byrne, 2010) or the value closer to 0.90 (Thadani \& Cheung, 2011). On the other hand, the recommended RMSEA should be less than 0.08 (Hoe, 2008; Steiger, 2007 cited by Hooper et al., 2008). However, Browne and Cudeck (1993) argue that RMSEA value of 0.08 indicates that the model fairly fits the data.

The incremental fit indices basically compare the Chi square value and baseline model to demonstrate the fitness of good model (Miles \& Shevlin, 2007). The incremental fit includes Adjusted Goodness of Fit Index (AGFI) which is obtained by adjusting GFI basing on the degree of freedom (Tabachnick \& Fidell, 2007). The Comparative Fit Index (CFI) is one of the Incremental Fit Indices that assesses the extent of un-correlation of the latent variable and attempt to compare the sample covariance matrix (ibid). The CFI's recommended index is at least 0.90 (Hair et al., 2010) while AGFI should be at least 0.80 (Chau \& $\mathrm{Hu}$, 2001). In the case of parsimony fit, CMIN was calculated in order to examine the goodness fit of the model. It is calculated by dividing the chi-square $\left(\lambda^{2}\right)$ with the degree of freedom (df), and it is recommended to be less that 5.0 (Bollen, 1989; Ullman, 1996).

The Cronbach's alpha coefficient was calculated in all variables in order to assess the internal consistency of the variables. Nunnaly (1967) argues that the 
Cronbach's alpha coefficient of at least 0.7 indicates an acceptable reliability statistic testing level. The Cronbach's alpha coefficient was at least 0.7 in all variables i.e. entrepreneurial orientation, business sales revenue and business costs. This indicates that all the tested items measured their constructs/variables. The construct reliability and validity were also assessed to ensure the reliability and validity of article findings. The value of construct reliability (CR) in Table 2 shows that the CR was attained in each factor. This was because CR coefficients were higher than 0.7 , the recommended value for CR coefficient. The AVE coefficients were all above 0.5 which indicated that the convergent validity in each construct had been attained. In the case of discriminant validity, the square root values of AVE were higher than the inter-factor correlations as shown in Table 2.

Table 2 includes the CR, AVE, square root values of AVE and inter-factor correlations that were used to assess the $\mathrm{CR}$, convergent validity and discriminant validity. CR coefficients in Table 2 were between 0.857 and 0.967 which were higher than the cut-off point of 0.7. AVE values were in between 0.504 and 0.914 that were higher than the cut-off point of 0.5 and indicated that there was convergent validity. Moreover, the square root values of AVE in all constructs were higher than the inter-factor correlations which indicated that there was discriminant validity.

\section{Research Results}

\subsection{Demographic Characteristics of the Respondents}

In the process of collecting quantitative data, 400 self-administered questionnaires were distributed to the respondents throughout the four regions, namely Dar es Salaam, Manyara, Mbeya and Morogoro. However, 388 questionnaires (97\%) out of 400 questionnaires were collected. Also, 224 questionnaires were distributed to respondents from micro businesses dealing with trade and 214 questionnaires (96\%) were actually collected. In the service sector, 121 questionnaires (98\%) out of 123 questionnaires were collected. In the manufacturing sector, 53 questionnaires were distributed and all (100\%) were collected from the respondents.

Out of the 388 business owners/operators, 315 (81.2\%) respondents were micro business owners and $73(18.8 \%)$ respondents were micro business operators.

Table 2. Reliability and Validity Tests.

\begin{tabular}{ccccccc}
\hline S/N & Variable & CR & AVE & $\begin{array}{c}\text { Entrepreneurial } \\
\text { Orientation(EO) }\end{array}$ & $\begin{array}{c}\text { Sales } \\
\text { Revenue }\end{array}$ & Costs \\
\hline 1 & EO & 0.857 & 0.524 & 0.724 & & \\
2 & Sales Revenue & 0.938 & 0.654 & $0.653^{\star *}$ & 0.809 & \\
3 & Costs & 0.967 & 0.914 & $-0.343^{* *}$ & $-0.410^{* *}$ & 0.956 \\
\hline
\end{tabular}

Source: Field Data. Note: The shaded figures are the square root values of AVE. ${ }^{\star *}$ means it is significant at 0.01 . 
Also, 209 (53.9\%) respondents were female and 179 (46.1\%) were male. Basing on the marital status, 188 (48.5\%) of the respondents were married, and 109 (28.1\%) of the respondents were single. Respondents who were divorced were 20 (5.2\%), widows/widowers were $63(16.2 \%)$ and others were 8 (2\%). Others included the ones who were separated or living together but not yet married. In terms of age, respondents whose age was between 20 and 25 years were 143 (36.9\%). Moreover, respondents whose age interval was in between 46 and 55 were 107 (27.6\%) and 26 - 45 years were 105 (27.1\%). Only 33 (8.5\%) of the respondents were between 56 and 60 years old.

In terms of business experience, the majority of the respondents i.e. 240 (61.9\%) had been engaged into the business for the period of 2 to 4 years. In addition, 140 (36.1\%) had a business experience of 5 to 9 years and only 8 (2\%) respondents had a business experience of at least 9 years. Basing on educational level, 196 (50.5\%) of the respondents had primary school education while in the higher end, 7 (1.8\%) of the respondents had postgraduate qualification. More details are shown in Appendix 1.

\subsection{Enterprise Characteristics}

The research involved 388 micro businesses from Dar es Salaam, Mbeya, Morogoro and Manyara. Out of 388 micro businesses, 150 (38.7\%) micro businesses were from Dar es Salaam, 155 (39.9\%) from Mbeya, 42 (10.8\%) from Morogoro and $41(10.6 \%)$ were from Manyara. The majority of the contacted micro businesses dealt with trade followed by the ones that dealt with services. The descriptive statistics show that 214 (55\%) micro businesses were in trade, 121 (31\%) dealt with service provision and, 53 (14\%) were the manufacturing businesses.

In terms of ownership, 327 (84.3\%) micro businesses were sole proprietorship businesses while 61 (15.7\%) were partnership businesses. In the case of partnership, the contacted micro businesses were said to be owned by the family and close relatives. Moreover, 295 (76\%) micro businesses were established in the past 2 to 4 years while $85(22 \%)$ had 5 - 7 years since their establishment. Only 8 $(0.8 \%)$ micro businesses were established at least 8 years ago. Summarised information are shown in Appendix 2.

\subsection{Description of Key Variables}

\subsubsection{Entrepreneurial Orientations}

Entrepreneurial orientations included proactive behavior and risk taking behavior. Generally, application of proactive behavior and risk taking behavior was at a medium level with a Mean score of 2.97 and 3.01 respectively. Despite the fact that the application of proactive behavior by micro businesses was at the medium level, business forecasting and, introduction of new products and business strategy before competitors were the leading factors under proactive behavior with a Mean score of 2.96 and 2.90 respectively. Under risk behavior, the adoption of bold strategy to maximise the probability of exploiting opportunities un- 
der uncertainties was the leading factor $(M=3.02)$. But, comparatively, most of micro business owners/operators who demonstrated entrepreneurial orientations, were more of risk takers $(M=3.01)$ than being proactive $(M=2.97)$. Also, the Mean scores of the specific items for proactive behavior ranged between 2.88 to 2.96 while for the risk-taking behavior ranged between 3.00 and 3.02. Summarised information are shown in Appendix 3.

\subsubsection{Business Sales Revenue}

Most of the micro businesses reported the increase in business sales revenue ( $M$ $=4.00$ ). This was contributed by the fact that majority of micro businesses (i.e. $86 \%$ ) were mobile money users and only $14 \%$ were non-mobile money users. Specifically, majority of micro businesses reported the steady increase in sales revenue $(M=4.03)$, increase in sales from neighboring individual customers ( $M$ $=4.01)$, return on sales above expectation $(M=4.01)$ and cash sales $(M=4.01)$. However, the moderate number of micro businesses reported an increase in sales from distant customers $(M=3.04)$. Summarised information are shown in Appendix 3.

\subsubsection{Business Costs}

Generally, the majority of micro businesses reported the decrease in business costs $(M=3.62)$ despite the fact that they were slightly below the ones reported an increase in sales revenue $(M=4.00)$. Specifically, majority of micro businesses reported the decrease in purchase costs $(\mathrm{M}=4.21)$, decrease in transaction costs per single purchase $(M=4.03)$, and the low transaction costs of receiving money $(M=3.61)$ and sending money $(M=3.50)$. However, the moderate number of businesses reported the decrease in the costs of sales $(M=2.64)$, follow-up costs $(M=2.63)$ and transaction cost per sales $(M=2.61)$. Summarised information are shown in Appendix 3.

\subsection{Assumptions for Using SEM}

Assumptions were tested to examine whether SEM could be used to analyse the collected data. These assumptions included the test for linear relationship, multicollinearity, normal distribution and outliers. The normal probability to probability (P-P) plot was used to test for linearity and indicated that there was a linear relationship among variables. In the case of multicollinearity, value inflated factor (VIF) and tolerance value showed that there was no multicollinearity problem because VIF values of all variables were less than 10 while tolerance values were more than 0.1 as suggested by Williams (2015). The results from the outlier labeling test also indicated that there were no outliers. Results from Shapiro Wilks $\mathrm{W}$ test also showed that data were normally distributed because it was insignificant in all variables. The model fit indices also revealed that model fitted the data well. CMIN/df was 1.532. GFI $=0.946$; AGFI $=0.929 ; \mathrm{CFI}=0.987$ and RMSEA $=0.07$. The Chi-square of 199.137 was insignificant at 0.142 which indicated that the departure of data from the model was insignificant. 


\subsection{Entrepreneurial Orientations and Micro Business Financial Performance}

\subsubsection{Proactive Behavior and Business Financial Performance}

The article hypothesized that proactive behavior influences micro business sales and costs. The structural equation modeling results revealed that proactive behavior had significant positive relationship with business sales $(\beta=0.82$, sig at $0.001)$. The results further revealed that proactive behavior had significant negative relationship with business costs. The path coefficient was -0.52 and significant at 0.001 . In this case, micro businesses that were proactive performed well financially because the business sales were increasing while business costs were decreasing.

With this fact, $\mathrm{H}_{1 \mathrm{a}}$ and $\mathrm{H}_{1 \mathrm{~b}}$ were fully supported. However, the findings also revealed that the proactive behaviour had more influence on the business sales than the business costs because the Beta coefficient $(\beta)$ on proactive behaviour-business sales relationship was 0.82 while that of proactive behaviour-business cost relationship was -0.52 . Specifically, the influence of proactive behaviour on micro business sales were attributed by an ability of entrepreneurial micro business owner or operator on business forecasting, introduction of new products and business strategy before competitors, commencing of actions before competitors and responding to actions initiated by competitors.

\subsubsection{Risk Taking Behavior and Micro Business Financial Performance}

The results revealed that risk taking behavior insignificantly influenced business sales $(\beta=0.07$, Sig. at 0.094$)$ and business costs $(\beta=0.13$ Sig. at 0.109$)$. In this fact, $\mathrm{H}_{2 \mathrm{a}}$ was supported while $\mathrm{H}_{2 \mathrm{~b}}$ was rejected. The results thus showed that risk taking behavior increased business sales but did not have an influence on business costs. In this fact, strong tendency for moderate risk behavior, adoption of cautious "wait and see" strategy uncertainty and adoption of bold strategy to maximize probability of exploiting opportunities under uncertainties by micro business owners/operators largely influenced the micro business sales. The insignificant influence of risk taking behaviour on micro business costs was attributed by the relatively low influence of risk taking behaviour on the purchase cost and the transaction cost per single purchase. Figure 1 presents the summary of the results.

\section{Discussion of Findings}

The article hypothesised that proactive behavior influences micro business sales and costs. The results showed the significant positive influence of proactive behavior on business sales and significant negative influence business costs. This implies that proactive behaviour significantly influenced micro business financial performance. The results were in line with the results of other empirical studies (such as Lumpkin \& Dess, 2001; Mahmood \& Hanafi, 2013; Semrau et al., 2016; Rezaei \& Ortt, 2018). Lumpkin and Dess (2001) argue that proactive 


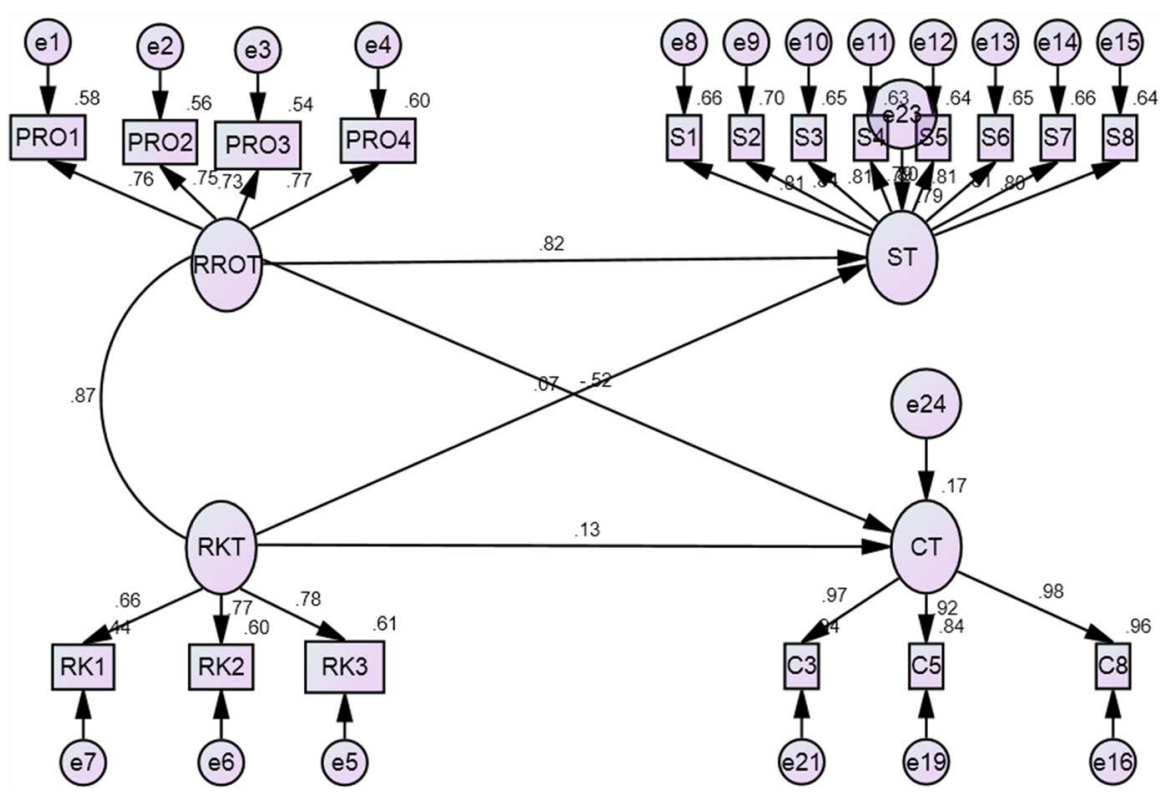

Figure 1. Indicates the direct relationship between entrepreneurial orientations and business financial performance. Entrepreneurial orientations were proactive behavior and risk taking behavior while the financial performance indicators were business sales and business costs. The path coefficient of proactive behavior and business sales was 0.82 while that of proactive behavior and business costs was -0.52 . On the other hand, the path coefficient between risk taking behavior and business sales was 0.07 and that of risk taking behavior and business costs was 0.13 .

behaviour have an influence on firm financial performance which was measured in terms sales growth. Rezaei and Ortt (2018) also confirm that proactive behaviour has an influence on firm sales and market performance. The results were also in line with the study by Semrau, Ambos, \& Kraus (2016) who contend that proactive behavior enhances ability to perform well.

The mentioned empirical studies revealed the positive relationship between entrepreneurial orientations and business performance. However, this article went further to explain the influence of proactive behaviour on business sales and costs as the individual dimensions of financial performance. In this case, the article revealed that proactive behaviour has relatively higher influence on business sales than in business costs despite the fact its influence in business sales and costs were both significant. The results were also in line with the contingency approach of examining entrepreneurial orientations and firm performance as shown by Lumpkin and Dess (2001). Lumpkin and Dess (2001), using the contingency perspective, opine that proactive behavior enhances firm performance under dynamic environments where business conditions are rapidly changing.

The results further revealed that risk taking behaviour has significant influence on micro business sales and insignificant influence on micro business costs. This implied that risk taking behavior has different influence on business sales and business costs. The results are supported with the prior empirical studies (Davis, Bell, Pyne, \& Kreiser, 2010; Kraus et al., 2012). For instance, Davis, Bell, 
Pyne, \& Kreiser, 2010 argue that tolerance risk behaviour by top managers positively influences firm performance. Kraus et al. (2012) also argue that risk orientation positively influences business growth. On the contrary, other empirical studies (such as Hughes \& Morgan, 2007; Lechner \& Gudmundsson, 2014; Kollman \& Stockman, 2014) argue that risk taking behaviour has negative influence on firm performance. It was also supported by Olaniran et al. (2016) who opine that risk taking behaviour has negative influence on return on assets (ROA) and return on equity (ROE). However, Olaniran et al. (2016) focused on the firms that were listed in the Nigerian Stock Exchange only. Likewise, Rezaei and Ortt (2018) argue that risk taking behaviour negatively influences production performance. Furthermore, Kosa et al. (2018) contend that risk-taking behaviour has a negative influence on firm performance. However, they recommended that a firm should take a calculated risks meanwhile allow their employees to take it in order for the risk-taking behaviour to positively influence firm performance.

\section{Conclusion}

The article examined the influence of entrepreneurial orientation and micro business financial performance. Specifically, the article examined the influence of proactive behavior and risk taking behavior on business sales and business costs. The results revealed that proactive behavior had a significantly positive influence on micro business financial sales and significantly negative influence on business costs. It was also revealed that risk-taking behavior had significantly positive influence on micro business sales only. Moreover, proactive behaviour and risk-taking behaviour have different influence on business sales and business costs. The proactive behaviour has different influence on business sales and costs. The proactive behaviour has relatively higher influence on business sales than on business costs.

Regarding the proactive behaviour, majority of micro business owners/operators demonstrated entrepreneurial ability on business forecasting, introduction of new products and business strategy before competitors, commencing of actions before competitors and responding to actions initiated by competitors. The aforementioned proactive behaviour dimensions together explain the influence of proactive behaviour on micro business sales and costs. Moreover, strong tendency for moderate risk behavior; adoption of cautious "wait and see" strategy uncertainty and; adoption of bold strategy to maximize probability of exploiting opportunities under uncertainties together explain the influence of risk-taking behaviour on business sales.

\section{Recommendations}

Recommendations were divided into two categories, i.e. recommendations to the government and recommendations to the micro business owners and operators. In addition, recommendations were guided by the research results. The follow- 
ings are the recommendations that are suggested by this article:

\subsection{Recommendations to the Government}

Proactive behaviour was found to have significant influence on micro business financial performance. It was revealed that micro businesses performed well financially when a micro business owner/operator is entrepreneurially oriented. This implies that businesses that are led by business owners/operators who are entrepreneurially oriented perform better financially. Due to this, it is important for the government to promote the development of entrepreneurial orientation among micro business owners/operators in order to improve micro business financial performance. The government may enhance entrepreneurial ability of the existing and potential micro business owners/ operators if the following things are implemented:

- Introduce entrepreneurship education from the nursery school to the higher learning institutions. Tanzania introduced the National Entrepreneurship Education and Training Framework for the sake of guiding formal and informal entrepreneurship education and trainings. In case of formal education, the Framework requires an introduction of entrepreneurship education programmes from the nursery level to the higher learning institution. However, the reality is different whereby entrepreneurship educational programmes are widely implemented at the higher learning institutions which eave the majority of Tanzanians at the lower educational levels, hence less equipped with entrepreneurial skills,

- Ensure the effective coordination, monitoring and evaluation of entrepreneurial trainings in the country. This may include certification of all institutions that offer entrepreneurial trainings outside the formal schooling system,

- Strengthen the National Economic Empowerment Council and other related institutions to spread entrepreneurial knowledge, skills and awareness in the country,

- To translate the National Entrepreneurship Education and Training Framework into Kiswahili to guide the entrepreneurship trainings at the local level,

- Through the Ministry of Education and Vocational Trainings, the government may establish entrepreneurship clubs and inter-school entrepreneurship competitions,

- The government, through local government authorities, may establish entrepreneurship hubs at the district level to promote and coordinate all entrepreneurship activities at the district level.

\subsection{Recommendations to the Micro Businesses}

Micro business owners/operators should entrepreneurially orient themselves in order to proactively identify and exploit both opportunities in the neighbouring and distant markets meanwhile reducing the business costs. Through proactive and risk-taking behaviour, micro businesses can be able to identify market cha- 
racteristics and demands, and new market opportunities that improve business sales revenue while looking for the cheapest sources of business inputs. The micro businesses may promote their proactive behaviour to influence both business sales and business costs meanwhile promoting risk-taking behaviour to influence business sales. Micro businesses should therefore develop their entrepreneurial capability. This can be achieved by attending entrepreneurship trainings that some of them are fully funded. Moreover, they may form their association, on the sectoral basis that can improve their ability to organise and access professional entrepreneurial trainings.

\section{Limitations}

Entrepreneurial orientations may not have the same influence on business financial performance across micro business sectors. In Tanzania, micro businesses have been categorised into three groups. There are micro businesses that are dealing with trade, services and manufacturing (MoIT, 2012). The mentioned micro business sectors differ in terms of business characteristics which may result to a different influence of entrepreneurial orientations on micro business financial performance. This article did not consider the influence of entrepreneurial orientations on micro business financial performance across their sectors. However, it does not dispute the fact that entrepreneurial orientations influence micro business financial performance. Focusing on micro business sectors, the findings would explain whether entrepreneurial orientations have different influence on micro business financial performance across their sectors.

In addition, the article used quantitative research methods which were not able to provide in-depth information on some of the findings. For instance, the article finding revealed that risk-taking behaviour does not have an influence on business costs. It was further revealed that proactive behaviour has higher influence on business sales than on business costs. The aforementioned findings demand the qualitative information to explain the reasons for such findings.

\section{Area for Further Studies}

The article finding revealed that risk-taking behaviour does not have an influence on business costs. It was further revealed that proactive behaviour has higher influence on business sales than on business costs. In this fact, it is recommended that the qualitative study should be carried out in order to have in-depth information on the aforementioned relationships. Furthermore, it is important to research on the influence of entrepreneurial orientations on business financial performance across micro business categories, i.e. trade, services and manufacturing.

\section{Conflicts of Interest}

The authors declare no conflicts of interest regarding the publication of this paper. 


\section{References}

Adahl, S. (2007). Poverty in Tanzania: An Analysis of Impoverishment in Morogoro and Kilombero Districts. KEPA. https://www.kepa.fi/tiedostot/julkaisut/poverty-in-tanzania.pdf

Agboli, M., \& Ukaegbu, C. C. (2006). Business Environment and Entrepreneurial Activity in Nigeria: Implications for Industrial Development. Journal of Modern African Studies, 44, 1-30. https://doi.org/10.1017/S0022278X05001394

Ahlin, B., Drnovsek, M., \& Hisric, R. D. (2012). Moderating Effect of Proactivity on the Relationship between Market Information and Innovation Performance. Economic and Business Review, 14, 121-146.

Ahmad, S., \& Ghan, A. H. A. (2010). The Relationship between Entrepreneurial Orientation and Business Performance of Malaysia SMEs. 2nd International Conference on Arab-Malaysian Islamic Global Business and Entrepreneurship, Jordan \& Syria, 20-24 March 2010, 120-135.

Ahuja, R. (2001). Research Methods. New Delhi: PremRawat.

Avlonitis, G. J., \& Salavou, H. E. (2007). Entrepreneurial Orientation of SMEs, Product Innovativeness, and Performance. Journal of Business Research, 60, 566-575. https://doi.org/10.1016/j.jbusres.2007.01.001

Bisbe, J., Coenders, G., Saris, W. E., \& Batis-Foguet, J. (2006). Correcting Measurement Error Bias in Interaction Model with Samples. Metodoloski zvezki, 3, 267-287.

Bollen, K.A. (1989). Structural Equations with Latent Variables. New York, NY: John Wiley \& Sons, Inc.

Botchkarev, A., \& Andru, P. (2011). A Return on Investment as a Metric for Evaluating Information Systems: Taxonomy and Application. Interdisciplinary Journal of Informational, Knowledge and Management, 6, 245-269. https://doi.org/10.28945/1535

Brege, H., \& Kindstrom, D. (2020). Exploring Proactive Market Strategies. Industrial Marketing Management, 84, 75-88. https://doi.org/10.1016/j.indmarman.2019.05.005

Browne, M. W., \& Cudeck, R. (1993). Alternative Ways of Assessing Model Fit. In K. A. Bollen, \& J. S. Long (Eds.), Testing Structural Equation Models (pp. 136-162). Newbury Park, CA: Sage.

Burns, T., \& Stalker, G. M. (1961). The Management of Innovation. London: Tavistock Publications.

Byrne, B. M. (2010). Structural Equation Modeling with AMOS: Basic Concepts, Application and Programming. New York, NY: Routledge.

Carton, R., \& Hofer, C. (2006). Measuring Organisational Performance: Metrics for Entrepreneurship and Strategic Management Research. Great Britain: Edward Elgar Publishing.

Chau, P. Y. K., \& Hu, P. J. H. (2001). Information Technology Acceptance by Individual Professional: A Model Comparison Approach. Decision Sciences, 32, 699-719. https://doi.org/10.1111/j.1540-5915.2001.tb00978.x

Davis, J. L., Bell, R. G., Pyne, G. T., \& Kreiser, P. M. (2010). Entrepreneurial Orientation and Firm Performance: The Moderating Role of Managerial Power. American Journal of Business, 25, 41-54. https://doi.org/10.1108/19355181201000009

Diyamett, D. (2012). The Role and Effect of Microfinance Institutions Loan on Innovativeness in Micro and Small Enterprises. Dar es Salaam: Dar es Salaam University Press. 
Elmore, P. E., \& Beggs, D. L. (1975). Salience of Concepts and Commitment to Extreme Judgments in Response Pattern of Teachers. Education, 95, 325-334.

Escribá-Esteve, A., Sánchez-Peinado, L., \& Sánchez-Peinado, E. (2008). Moderating Influences on the Firm's Strategic Orientation-Performance Relationship. International Small Business Journal, 26, 463-489. https://doi.org/10.1177\%2F0266242608091174

Gray, G. T., \& Wert-Gray, S. (2012). Approach to Marketing Entrepreneurship: Impact of Business Strategies on the Firm's Marketing Function. International Journal of Business, Humanities, and Technology, 2, 184-191.

Hair, J. F., Black, W. C., Babin, B. J., \& Anderson, R. E. (2010). Multivariate Data Analysis (7th ed.). Upper Saddle River, NJ: Prentice Hall.

Hinkin, T. R. (1995). A Review of Scale Development Practices in the Study of Organizations. Journal of Management, 21, 967-988. https://doi.org/10.1177\%2F014920639502100509

Hoe, S. L. (2008). Issues and Procedure in Adopting Structural Equation Modeling Technique. Journal of Applied Quantitative Methods, 3, 76-83.

Holloway, I. (1997). Basic Concepts for Qualitative Research. Oxford: Blackwell Science.

Hooper, D., Coughlan, J., \& Mullen, M. (2008). Structural Equation Modeling: Guidelines for Determining Model Fit. Electronic Journal of Business Research Methods, 6, 53-60.

Hughes, M., \& Morgan, R. E. (2007). Deconstructing the Relationship between Entrepreneurial Orientation and Business Performance at the Embryonic Stage of Firm Growth. Industrial Marketing Management, 36, 651-661. https://doi.org/10.1016/j.indmarman.2006.04.003

Inegbenebor, A. U. (2006). Financing Small and Medium Industries in Nigeria-Case Study of the Small and Medium Industries Equity Investment Scheme (SMIEIS): Empirical Research Findings. Journal of Financial Management and Analysis, 19, 71-80.

Jackson, J. L., Dezee, K., Douglas, K., \& Shimeall, W. (2005). Introduction to Structural Equation Modeling: Path Analysis. http://impak.sgim.org/userfiles/file/AMHandouts/AM05/handouts/PA08.pdf

Kaiser, K., \& Bostrom, R. (1982). Personality Characteristics of MIS Project Teams: An Empirical Study and Action Research Design. MIS Quarterly, 6, 43-60. https://doi.org/10.2307/249066

Kessy, S., \& Temu, S. S. (2010). The Impact of Training on Performance of Micro and Small Enterprises Served by Micro Institutions in Tanzania. Research Journal of Business Management, 4, 103-111. https://doi.org/10.3923/ribm.2010.103.111

Kiggunda, M. (2002). Entrepreneurs and Entrepreneurship in Africa: What Is Known Needs to Be Done. Journal of Developmental Entrepreneurship, 7, 239-258.

Kollman, T., \& Stockman, C. (2014). Filling the Entrepreneurial Orientation Performance Gap: the Mediating Effects of Exploratory and Exploitative Innovations. Entrepreneurship: Theory \& Practice, 38, 1001-1026. https://doi.org/10.1111\%2Fj.1540-6520.2012.00530.x

Kosa, A., Mohammad, I., \& Ajibie, D. (2018). Entrepreneurial Orientation and Venture Performance in Ethiopia: The Moderating Role of Business Sector and Enterprise Location. Journal of Global Entrepreneurship Research, 8, Article No. 25. https://doi.org/10.1186/s40497-018-0110-x

Kraus, S., Rigtering, J.P.C., Hughes, M., \& Hosman, V. (2012). Entrepreneurial Orientation and the Business Performance of SMEs: A Quantitative Study from the Netherlands. Review Management Science, 6, 161-182. 
https://doi.org/10.1007/s11846-011-0062-9

Krejcie, R. V., \& Morgan, D. W. (1970). Determining Sample Size for Research Activities. Educational and Psychological Measurement, 30, 607-610. https://doi.org/10.1177\%2F001316447003000308

Lawrence, P. R., \& Lorsch, J. W. (1967). Organization and Environment. Boston, MA: Harvard Business School.

Lechner, C., \& Gudmundsson, S. V. (2014). Entrepreneurial Orientation, Firm Strategy and Small Firm Performance. International Small Business Journal, 32, 36-60. https://doi.org/10.1177\%2F0266242612455034

Li, Y., Guo, H., Liu, Y., \& Li, M. (2008). Incentive Mechanisms, Entrepreneurial Orientation, and Technology Commercialization: Evidence from China's Transitional Economy. Journal of Product Innovation Management, 25, 63-78. https://doi.org/10.1111/j.1540-5885.2007.00283.x

Liedholm, C. (2002). Small Firm Dynamics: Evidence from Africa and Latin America. Small Business Economics, 18, 225-240. https://doi.org/10.1023/A:1015147826035

Lumpkin, G. T., \& Dess, G. G. (1996). Clarifying the Entrepreneurial Orientation Construct and Linking It to Performance. The Academy of Management Review, 21, 135-172. https://doi.org/10.5465/amr.1996.9602161568

Lumpkin, G. T., \& Dess, G. G. (2001). Linking Two Dimensions of Entrepreneurial Orientation to Firm Performance: The Moderating Role of Environment and Industry Life Cycle. Journal of Business Venturing, 16, 429-451. https://doi.org/10.1016/S0883-9026(00)00048-3

Lumpkin, G., \& Dess, G. (2005). The Role of Entrepreneurial Orientation in Stimulating Effective Corporate Entrepreneurship. Academy of Management Executive, 19, 147-156. https://doi.org/10.5465/ame.2005.15841975

Macculloch, F. (2001). Government Administrative Burdens on SMEs in East Africa: Reviewing Issues and Actions. Economic Affairs, 21, 10-16. https://doi.org/10.1111/1468-0270.00287

Madrid-Guijarro, A., Auken, H., \& García-Pérez-De-Lema, D. (2007). An Analysis of Factors Impacting Performance of Spanish Manufacturing Firms. Journal of Small Business and Entrepreneurship, 20, 369-379. https://doi.org/10.1080/08276331.2007.10593406

Mahmood, R., \& Hanafi, N. (2013). Entrepreneurial Orientation and Business Performance of Women-Owned Small and Medium Enterprises in Malaysia: Competitive Advantage as a Mediator. International Journal of Business and Social Science, 4, 82-90.

Marwa, N. (2014). Micro, Small and Medium Enterprises' External Financing Challenges: The Role of Formal Financial Institutions and Development Finance Intervention in Tanzania. International Journal of Trade, Economics, and Finance, 5, 230-234. https://doi.org/10.7763/IJTEF.2014.V5.376

Mashimba, H., \& Kühl, R. (2014). Performance of Micro and Small-Scale Enterprises (MSEs) in Tanzania: Growth Hazards of Fruit and Vegetables Processing Vendors. Journal of Applied Economics and Business Research, 4, 120-133.

Mbogo, M. (2010). The Impact of Mobile Payments on the Success and Growth of Micro-Business: The Case of M-Pesa in Kenya. The Journal of Language, Technology and Entrepreneurship in Africa, 2, 182-202. https://doi.org/10.4314/jolte.v2i1.51998

McDonald, R. P., \& Ho, M. R. (2002). Principles and Practice in Reporting Structural Equation Analysis. Psychological Methods, 7, 64-82. 
https://doi.apa.org/doi/10.1037/1082-989X.7.1.64

Mfaume, R., \& Leonard, W. (2004). Small Business Entrepreneurship in Dar es Salaam-Tanzania: Exploring Problems and Prospects for Future Development and Poverty Reduction: The Macro-Micro Linkage (pp. 1-28). Somerset West, South Africa: Cornell University.

Miles, J., \& Shevlin, M. (2007). A Time and A Place for Incremental Fit Indices. Personality and Individual Differences, 42, 869-874. https://doi.org/10.1016/j.paid.2006.09.022

Ministry of Industry and Trade (2012). National Baseline Survey Report: Micro, Small and Medium Enterprises in Tanzania. http://www.mit.go.tz/pdf/MSME\%20Pages\%20ST1 081513.pdf

Mnenwa, R., \& Maliti, E. (2009). Assessing the Institutional Framework for Promoting the Growth of MSEs in Tanzania. The Case of Dar es Salaam Research Report 08.6, Dar es Salaam: Research on Poverty Alleviation.

National Bureau of Statistics-NBS \& Regional Commissioner's Office (2014). Dar Es Salaam Socio-Economic Profile. Dar es Salaam: Prime Minister's Office Regional Administration and Local Government, Tanzania.

National Bureau of Statistics-NBS (2013). National Accounts of Tanzania Mainland 2001-2012. Dar es Salaam, Tanzania: Ministry of Finance.

Ndubisi, N., \& Iftikhar, K. (2012). Relationship between Entrepreneurship, Innovation and Performance: Comparing Small and Medium-Size Enterprises. Journal of Research in Marketing and Entrepreneurship, 14, 214-236.

https://doi.org/10.1108/14715201211271429

Neshamba, F. (2000). Growth and Transformation among Small Business in Kenya. Nottingham: The Nottingham Trent University.

Nunnaly, J. C. (1967). Psychometric Theory, New York: McGraw-Hill.

Nyello, R. (2018). Mobile Money Services, Entrepreneurial Orientations, and Business Financial Performance: A Case of Micro-Businesses in Tanzania. PhD Thesis, Dar es Salaam: University of Dar es Salaam Business School.

Olaniran, O., Namusonge, G. S., \& Muturi, W. (2016). The Role of Risk-Taking on Performance of Firms on Nigerian Stock Exchange. International Journal of Research in Business Studies and Management, 3, 36-44.

Olomi, D., (2009). African Entrepreneurship and Small Business Development. Dar es Salaam: Otme Publishers.

Pope, J. (2001). Confronting Corruption: The Elements of National Integrity System. London: Transparency International.

Pratt, V. (2001). Sharing Business Skills in Kenya. Washington DC: Center for International Private Enterprise. http://www.cipe.org

Radipere, S. (2014). The Effects of Entrepreneurial Orientation on Business Performance. Mediterranean Journal of Social Science, 5, 141-152.

https://doi.org/10.5901/mjss.2014.v5n16p141

Rauch, A., Wiklund, J., Lumpkin, G. T., \& Freese, M. (2004). Entrepreneurial Orientation and Business Performance: An Assessment of Past Research and Suggestion for the Future. http://www.blackwellpublishing.com/journal.asp?.ref=1042-2587\&site=1

Razaei, J., \& Ortt, R. (2018). Entrepreneurial Orientation and Firm Performance: The Mediating Role of Functional Performances. Management Research Review, 41, 878-900. https://doi.org/10.1108/MRR-03-2017-0092

Roscoe, J. T. (1975). Fundamental Research Statistics for the Behavioral Sciences (2nd 
ed.). New York, NY: Holt Rinehart \& Winston.

Rosenbusch, N., Rauch, A., \& Bausch, A. (2013). The mediating Role of Entrepreneurial Orientation in the Task Environment-Performance Relationship: A Meta-Analysis. Journal of Management, 39, 633-659. https://doi.org/10.1177\%2F0149206311425612

Scarborough, N. M., \& Zimmerer, T. W. (2008). Essentials of Entrepreneurship and Small Business Management (5th ed.). Upper Saddle River, NJ: Prentice Hall.

Semrau, T., Ambos, T., \& Kraus, S. (2016). Entrepreneurial Orientation and SME Performance across Societal Cultures: An International Study. Journal of Business Research, 69, 1928-1932. https://doi.org/10.1016/j.jbusres.2015.10.082

Small Industry Development Organization (SIDO) (2009). Subsector/Value Chain Analysis Report for Sunflower in Manyara Region. Dar es Salaam: Economic Research Bureau.

Soderbom, M., Teal, F., \& Harding, A. (2006). The Determinants of Survival among African Manufacturing Firms. Economic Development and Cultural Change, 54, 533-555. https://doi.org/10.1086/500030

Steiger, J. H. (2007). Understanding the Limitations of Global Fit Assessment in Structural Equation Modeling. Personality and Individual Differences, 42, 893-898. https://doi.org/10.1016/j.paid.2006.09.017

Syed, H. H., Muzaffar, A., \& Minaa, F. (2017). Entrepreneurial Orientation and Business Performance of Manufacturing Sector Small and Medium Enterprises in Punjab, Pakistan. European Business and Management Journal, 3, 21-28. https://doi.org/10.11648/j.ebm.20170302.12

Tabachnick, B. G., \& Fidell, L. S. (2007). Using Multivariate Statistics (5th ed.). New York, NY: Allyn and Bacon.

Thadani, D. R., \& Cheung, C. M. K. (2011). Online Social Network Dependency: Theoretical Development and Testing of Competing Models. 2011 44th Hawaii International Conference on System Sciences, Kauai, 4-7 January 2011, 1-9. https://doi.org/10.1109/HICSS.2011.331

Thisted, R. A. (2006). The Cross-Sectional Study: Investigating Prevalence and Association. Chicago, IL: The University of Chicago.

Ullman, J.B. (1996). Structural Equation Modeling. In B. G. Tabachnick, \& L. S. Fidell (Eds.), Using Multivariate Statistics (3rd ed., pp. 709-819). New York, NY: Harper Collins College Publishers.

Umoh, G. S. (2006). Empirical Investigation of Access to Micro-Credit in an Emerging Economy: Evidence from Nigeria. Journal of African Business, 7, 89-117.

https://doi.org/10.1300/J156v07n01 05

United Republic of Tanzania-URT (2003). SME Development Policy. Dar es salaam: Ministry of Industry and Trade (MIT).

Venkatraman, N. (1989). The Concept of Fit in Strategy Research: Toward Verbal and Statistical Correspondence. Academy of Management Review, 14, 423-444. https://doi.org/10.5465/amr.1989.4279078

Wales, W., Gupta, V., \& Mousa, F. (2013). Empirical Research on Entrepreneurial Orientation: An Assessment and Suggestions for Future Research. International Small Business Journal, 31, 357-383. https://doi.org/10.1177/0266242611418261

Wang, H., \& Yen, Y. (2012). An Empirical Exploration of CEO and Performance in Taiwanese SMEs: A Perspective of Multidimensional Construct. Total Quality Management and Business Excellence, 23, 1035-1044. 
https://doi.org/10.1080/14783363.2012.670917

Wang, X., \& Cheng, Z. (2020). Cross-Sectional Studies: Strengths, Weaknesses and Recommendations. Chest Journal, 158, S65-S71.

Weill, P., \& Oslon, M. (1987). An Assessment of the Contingency Theory of MIS. The Working Paper Series No. IS-87-31, New York, NY: The Center for Digital Economy Research.

Weiss, M. (1983). Effects of Work Stress and Social Support on MIS Managers. MIS Quarterly, 7, 29-43. https://doi.org/10.2307/249075

Wiklund, J., \& Shepherd, D. (2004). Entrepreneurial Orientation and Small Business Performance: A Configurational Approach. Journal of Business Venturing, 20, 71-91. https://doi.org/10.1016/j.jbusvent.2004.01.001

Williams, R. (2015). Multicollinearity, University of Notre Dame. https://www3.nd.edu/ rwilliam/stats2/111.pdf

Yang, J. T. (2008). Individual Attitudes and Organisational Knowledge Sharing. Tourism Management, 29, 345-353. https://doi.org/10.1016/j.tourman.2007.03.001

Yuksel, A., Yuksel, F., \& Bilim, Y. (2010). Destination Attachment: Effects on Customer Satisfaction and Cognitive, Affective and Conative Loyalty. Tourism Management, 31, 274-284. https://doi.org/10.1016/j.tourman.2009.03.007 


\section{Appendices}

\section{Appendix 1. Demographic Characteristics}

\begin{tabular}{|c|c|c|c|c|}
\hline S/No. & Details & Category & Frequency & Percent \\
\hline \multirow{3}{*}{1.} & \multirow{3}{*}{ Sex } & Male & 179 & 46.1 \\
\hline & & Female & 209 & 53.9 \\
\hline & & Total & 388 & 100 \\
\hline \multirow{5}{*}{2} & \multirow{5}{*}{ Age } & $20-25$ & 143 & 36.9 \\
\hline & & $26-45$ & 105 & 27.1 \\
\hline & & $46-55$ & 107 & 27.6 \\
\hline & & $55-60$ & 33 & 8.5 \\
\hline & & Total & 388 & 100 \\
\hline \multirow{6}{*}{3} & \multirow{6}{*}{ Marital Status } & Single & 109 & 28.1 \\
\hline & & Married & 188 & 48.5 \\
\hline & & Divorced & 20 & 5.2 \\
\hline & & Widow/ widower & 63 & 16.2 \\
\hline & & Others & 8 & 2 \\
\hline & & Total & 388 & 100 \\
\hline \multirow{10}{*}{4} & \multirow{10}{*}{ Educational Level } & Postgraduate qualification & 7 & 1.8 \\
\hline & & Degree/Advanced Diploma & 11 & 2.8 \\
\hline & & Ordinary Diploma & 18 & 4.6 \\
\hline & & Certificate & 15 & 3.9 \\
\hline & & Vocational/Technical Training & 50 & 12.9 \\
\hline & & “A” Level Education & 20 & 5.2 \\
\hline & & “O” Level Education & 47 & 12.1 \\
\hline & & Primary School & 196 & 50.5 \\
\hline & & No formal schooling & 24 & 6.2 \\
\hline & & Total & 388 & 100 \\
\hline \multirow{4}{*}{5} & \multirow{4}{*}{$\begin{array}{l}\text { Business Experience } \\
\quad \text { (in years) }\end{array}$} & $2-4$ & 240 & 61.9 \\
\hline & & $5-9$ & 140 & 36.1 \\
\hline & & Above 9 years & 8 & 2 \\
\hline & & Total & 388 & 100 \\
\hline \multirow{3}{*}{6} & \multirow{3}{*}{$\begin{array}{l}\text { Category of } \\
\text { respondents }\end{array}$} & Micro business owners & 315 & 81.2 \\
\hline & & Micro business operators & 73 & 18.8 \\
\hline & & Total & 388 & 100 \\
\hline
\end{tabular}




\section{Appendix 2. Enterprises' Characteristics}

\begin{tabular}{|c|c|c|c|c|}
\hline S/No. & Details & Category & Frequency & Percent \\
\hline \multirow{5}{*}{1.} & \multirow{5}{*}{$\begin{array}{c}\text { Geographical } \\
\text { location }\end{array}$} & Dar es salaam & 150 & 38.7 \\
\hline & & Mbeya & 155 & 39.9 \\
\hline & & Morogoro & 42 & 10.8 \\
\hline & & Manyara & 41 & 10.6 \\
\hline & & Total & 388 & 100 \\
\hline \multirow{4}{*}{2} & \multirow{4}{*}{ Business category } & Trade & 214 & 55 \\
\hline & & Services & 121 & 31 \\
\hline & & Manufacturing & 53 & 14 \\
\hline & & Total & 388 & 100 \\
\hline \multirow{3}{*}{3} & \multirow{3}{*}{ Ownership structure } & Sole proprietorship & 327 & 84.3 \\
\hline & & Partnership & 61 & 15.7 \\
\hline & & Total & 388 & 100 \\
\hline \multirow{4}{*}{4} & \multirow{4}{*}{$\begin{array}{l}\text { Establishment period } \\
\text { (years) }\end{array}$} & $2-4$ & 295 & 76 \\
\hline & & $5-7$ & 85 & 22 \\
\hline & & Above 7 & 8 & 2 \\
\hline & & Total & 388 & 100 \\
\hline
\end{tabular}

\section{Appendix 3. Descriptive Results}

\begin{tabular}{|c|c|c|c|}
\hline $\mathrm{S} / \mathrm{N}$ & Variable/Item & Mean & Remarks \\
\hline 1 & Proactive Behaviour & 2.97 & Medium \\
\hline 1.1 & Responding to actions initiated by competitors & 2.9 & Medium \\
\hline 1.2 & Event anticipation (Business forecasting) & 2.96 & Medium \\
\hline 1.3 & Initiate actions before competitors & 2.88 & Medium \\
\hline 1.4 & First to introduce new product and business strategy. & 2.92 & Medium \\
\hline 2 & Risk taking behavior & 3.01 & Medium \\
\hline 2.1 & Strong tendency for moderate risk behavior & 3 & Medium \\
\hline 2.2 & Adoption of cautious 'wait and see' strategy uncertainty & 3 & Medium \\
\hline 2.3 & $\begin{array}{l}\text { Adoption of bold strategy to maximize probability of exploiting } \\
\text { opportunities under uncertainties }\end{array}$ & 3.02 & Medium \\
\hline 3 & Business Sales Revenue & 4 & High \\
\hline 3.1 & Increase in Sales Volume & 4 & High \\
\hline 3.2 & Perceived increase in cash sales & 4.01 & High \\
\hline 3.3 & Perceived return on sales above the expectation & 4.01 & High \\
\hline 3.4 & Sales growth is good & 3.98 & High \\
\hline 3.5 & Steady increase in sales & 4.03 & High \\
\hline 3.6 & Sales is relatively higher than competitors sales & 4 & High \\
\hline
\end{tabular}




\section{Continued}

\begin{tabular}{clcc}
\hline 3.7 & Perceived increase in sales from neighboring customers & 4.01 & High \\
3.8 & Perceived increase in sales from distant customers & 3.04 & Medium \\
4 & Business costs & 3.62 & High \\
4.1 & Decrease in transactions costs per sales & 2.61 & Medium \\
4.2 & Decrease in transaction cost per single purchase & 4.03 & High \\
4.3 & Perceived decreased cost in purchase & 4.21 & High \\
4.4 & Perceived decrease in cost of sales & 2.64 & Medium \\
4.5 & Decrease in follow-up costs & 2.63 & Medium \\
\hline
\end{tabular}

